REVIEWS

\title{
Interventions to address medication-related causes of hospital readmissions: A scoping review
}

\author{
Nathan W. Carroll, Reena Joseph, Neeraj Puro \\ Department of Health Services Administration, University of Alabama at Birmingham, United States
}

Received: May 6, 2019

DOI: $10.5430 /$ jha.v8n4p10
Accepted: May 23, 2019

Online Published: June 3, 2019

\begin{abstract}
Unplanned readmissions pose a tremendous burden on patients, providers, and payers. A significant proportion of readmissions are medication-related. Despite the availability of literature regarding hospital-level strategies to reduce readmissions, little has been written about strategies aimed at medication-related readmissions. We sought to identify successful readmission reduction strategies by performing a scoping literature review of research published between 2000 and 2017. We identified 21 studies that met our inclusion criteria. From these studies, we identified 7 components frequently employed as a part of interventions to reduce medication-related readmissions: discharge planning, discharge education, post-discharge telephone calls, the use of a professional coordinator with clinical training to administer the intervention, patient education efforts, provider training efforts, and medication reconciliation. Thirty-eight percent of all the interventions identified were associated with a statistically significant reduction in readmissions. Of the 7 common intervention components we identified, none were consistently associated with intervention success in the full sample. However, interventions implemented by inpatient hospitals, in particular academic medical centers, had a higher success rate than interventions implemented by other providers. We examined a subsample of larger studies and found that discharge planning and medication reconciliation components were included in most of the successful interventions. Future research should look beyond simply identifying components included in an intervention and should instead seek to identify contextual factors that enable or inhibit the success of these components. Research examining discharge planning and medication reconciliation efforts will be particularly important.
\end{abstract}

Key Words: Hospital readmissions, Medication, Care transition

\section{INTRODUCTION}

Unplanned hospital readmissions pose a tremendous burden on patients, providers, and payers. In 2013, it was estimated that nearly $20 \%$ of all hospital admissions resulted in a subsequent unplanned readmission within 30 days from discharge. These readmissions were associated with over $\$ 41$ billion in additional costs to the health system. ${ }^{[1,2]}$ The high proportion of readmissions prove to be extremely costly and signal a marked deterioration in the quality of care delivery. In an effort to improve care quality and decrease the increasing cost of health care, the Patient Protection and Affordable Care Act of 2010 instituted the Hospital Readmission Reduction Program (HRRP), which required the Centers for Medicare and Medicaid Services (CMS) to impose penalties on hospitals with excess patient readmissions. Since the HRRP was introduced in 2012, hospitals have incurred nearly $\$ 2$ billion in penalties, including an estimated \$528 million in the past year. ${ }^{[3]}$ Efforts to reduce readmissions have primarily been aimed at addressing pre- or post-discharge needs, in the form of patient education, discharge planning, im-

*Correspondence: Nathan W. Carroll; Email: natcar@uab.edu; Address: University of Alabama at Birmingham, United States. 
proved communication with providers, and medication reconciliation. ${ }^{[4]}$ Among the different factors contributing to unplanned hospital readmissions, medication-related causes, including adverse drug events, have been studied extensively. It has been estimated that adverse drug events may account for $13 \%-20 \%$ of unplanned readmissions, indicating that medication-related readmissions have significant implications for patients and providers. ${ }^{[5,6]}$

Despite the availability of literature regarding hospital level strategies to reduce readmissions ${ }^{[4,7,8]}$ relatively little has been written about strategies and guidelines specifically aimed at reducing medication-related readmissions. Prior studies have separately conducted and evaluated interventions that are pharmacist-led, ${ }^{[9,10]}$ nurse practitioner-led, ${ }^{[11]}$ jointly led by pharmacists and nurses, ${ }^{[12]}$ aimed at improving communication between providers during care transition, ${ }^{[13-15]}$ or have identified potential patient or administrative risk factors for medication-related readmissions. ${ }^{[16,17]}$ However, no studies have conducted a comprehensive review of the different types of interventions, including an evaluation of the types of providers initiating interventions, the components employed by each intervention, and the overall effectiveness of the intervention. The purpose of this paper is to identify the different interventions aimed at reducing medication-related unplanned readmissions and to identify the characteristics associated with successful reductions in readmissions.

\section{MethodS}

We performed a scoping literature review of studies that examined medication-related causes of hospital readmissions. Our initial search strategy was to identify studies that examined the effectiveness of specific interventions as well as those that identified patient risk-factors for medicationrelated readmissions. However, after reviewing the available literature, the study authors decided to limit the review to studies that examined interventions alone, since these studies may better-inform efforts to reduce medication-related readmissions than studies that identify risk factors. Our bibliographic search started with three electronic databases, Scopus, PubMed, and CINAHL, to identify studies that met our criteria.

\subsection{Inclusion criteria}

Our search terms included medical sub-heading (MeSH) terms related to "medication adherence" or "drug-related side effects", including "medication compliance", "medication nonadherence", "medication persistence", "adverse drug reactions", "adverse drug events" and "drug side effects". To be included in our review, the study had to include one of these terms along with a term related to patient readmissions, specifically "hospital readmissions", "patient readmissions" or "30-day readmissions". Additionally, we restricted our search to studies published in English language, peer-reviewed journals between 2000 and 2017.

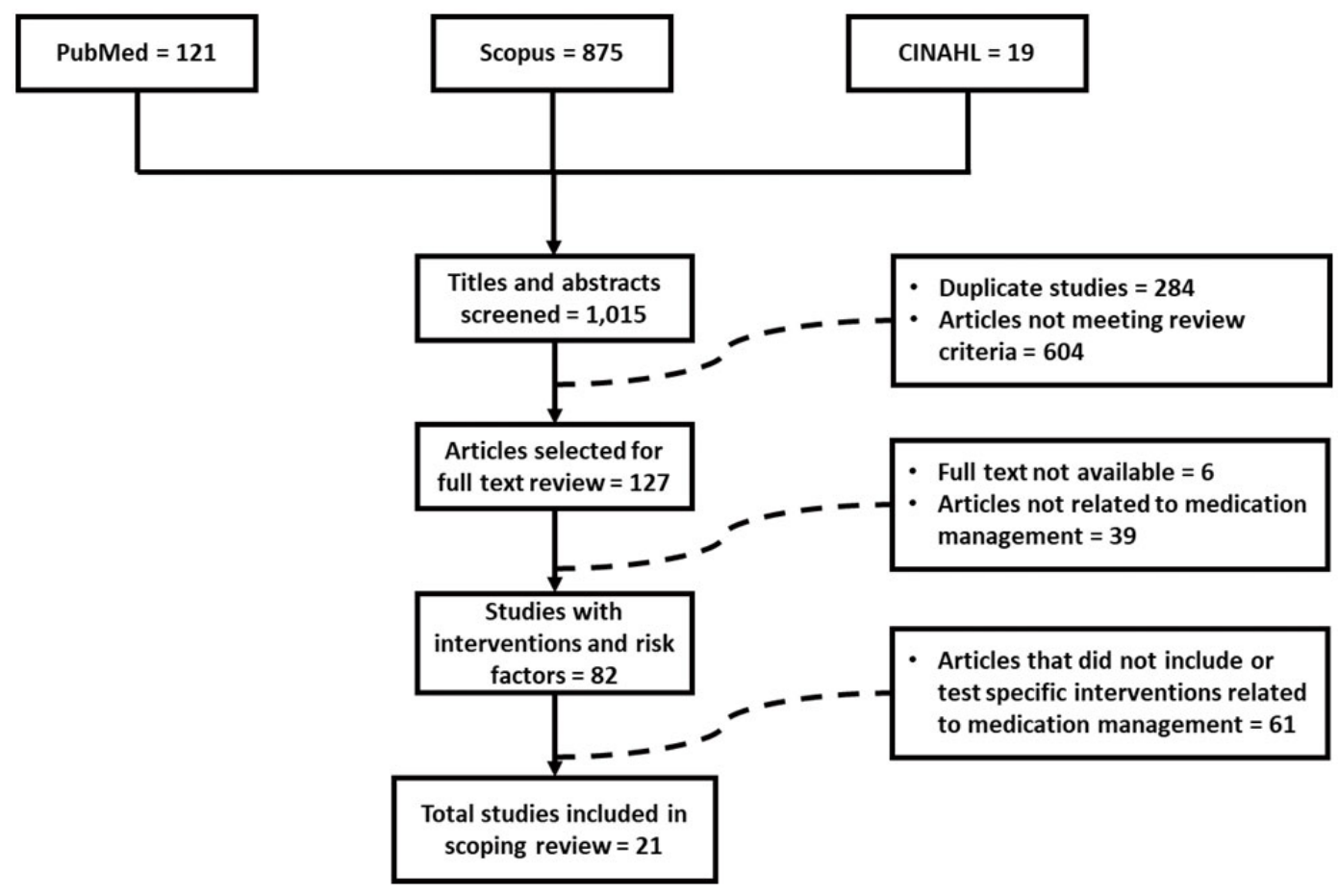

Figure 1. Study selection process for the literature search on interventions to reduce medication-related hospital readmissions 


\subsection{Exclusion criteria}

We excluded commentaries, opinion articles, and articles that only reported study protocols. In addition, we excluded studies that focused exclusively on pediatric populations or patients with mental health conditions since interventions that successfully reduce readmissions among these populations may not be equally effective if applied to the general patient population. Studies were also excluded from our review if they did not include a specific intervention program aimed at reducing hospital readmissions due to medicationrelated causes.

Our initial search identified 1,015 articles from all three databases. The text and abstracts of each article were reviewed by one of the study authors to identify duplicates and to assess whether the identified studies met our review requirements. Two hundred eighty-four (284) duplicates and an additional 604 articles were excluded for failure to meet the inclusion criteria. This left 127 articles for full text review. Six (6) articles were further eliminated from our review due to the unavailability of full text, and 39 were excluded because they did not pertain to medication management, leaving a total of 82 articles. Finally, we excluded studies that only examined the risk-factors for medicationrelated readmissions or did not examine the effectiveness of an intervention designed to reduce readmissions. This step yielded a final total of 21 studies to be included in our review. Figure 1 shows the flow of article selection.

After reviewing all 21 articles included in the study, the three study authors conferred to identify specific strategies or "components" that were commonly used in readmission reduction efforts and worked collaboratively to develop definitions for these components. Based on the definitions, two of the study authors independently categorized the interventions employed in each article into its individual components. When the authors disagreed they met and discussed the intervention until consensus was reached.

Table 1. Detailed definitions of intervention components

\begin{tabular}{|c|c|}
\hline Intervention component & Description \\
\hline Discharge planning & $\begin{array}{l}\text { Occurs when a clinician works with multiple members of the care team from different disciplines to } \\
\text { develop a plan for the patient's post-discharge care and medication regimen. }\end{array}$ \\
\hline Discharge education & $\begin{array}{l}\text { Provided prior to hospital discharge. Discharge education may be related to treatment, medications and } \\
\text { the importance of adherence to the prescribed regimen. It may be provided by the physician, nurse, } \\
\text { pharmacist or any other designated provider on the care team. }\end{array}$ \\
\hline Post-discharge phone call & $\begin{array}{l}\text { Post discharge phone call- phone calls made to patient anywhere from } 24 \text { hours to } 14 \text { days following } \\
\text { discharge. Goal is to ensure that patient understands and adheres to all aspects of the medication } \\
\text { regimen. }\end{array}$ \\
\hline $\begin{array}{l}\text { Use of a professional } \\
\text { coordinator }\end{array}$ & $\begin{array}{l}\text { May include a nurse, advanced practice clinician, pharmacist or physician working to coordinate care } \\
\text { following patient discharge from the hospital. The professional coordinator acts to improve } \\
\text { communication between clinicians caring for patients in an acute care setting and those providing care } \\
\text { outside the hospital. The professional coordinator may be based in the hospital or in the community. }\end{array}$ \\
\hline $\begin{array}{l}\text { Patient education and } \\
\text { counseling }\end{array}$ & $\begin{array}{l}\text { This involves educating the patient or an informal caregiver about the patient's treatment, medications } \\
\text { or the importance of adherence to the prescribed regimen. This is similar to discharge education except } \\
\text { it occurs after the patient has been discharged. }\end{array}$ \\
\hline Provider education & $\begin{array}{l}\text { Goal is to teach physicians, nurses and other individuals in the care team to recognize their roles within } \\
\text { the interdisciplinary team, to ensure safe patient transitions across the care continuum, and/or to } \\
\text { educate patients regarding the importance of following the prescribed treatment regimen. }\end{array}$ \\
\hline Medication reconciliation & $\begin{array}{l}\text { Interventions that offer some enhancement to the medication reconciliation provided as usual care. This } \\
\text { can occur either at the time of hospital discharge, at the time of admission or during post-discharge } \\
\text { follow-up care. }\end{array}$ \\
\hline
\end{tabular}

\section{Results}

\subsection{Characteristics of interventions}

The 21 studies we reviewed evaluated the success of intervention programs designed to address medication-related determinants of hospital readmissions. Within our sample of studies we identified 7 commonly employed components of interventions for reducing medication-related readmissions: discharge planning, discharge education, post-discharge telephone calls, the use of a professional coordinator with clinical training to administer the intervention, patient education efforts, provider education efforts, and medication reconciliation. Detailed descriptions of each of these intervention components are provided in Table 1. These categories are similar to the intervention elements identified in literature 
reviews targeting all causes of readmissions, rather than just targeting medication-related causes. ${ }^{[4,18]}$

Of the 21 sample studies, only two ${ }^{[19,20]}$ had a single intervention component, while 12 studies included four or more intervention components. ${ }^{[21-32]}$ Several of the intervention components were employed in many of the studies we examined. Discharge planning (used in 7 studies) and provider education (used in 2 studies) were the least-often used intervention components.

\subsection{Program effectiveness}

Only 8 of the 21 interventions (38\%) studied resulted in statistically significant reductions in readmission rates while the majority of interventions were not associated with a statistically significant decrease in medication-related readmissions. The observed heterogeneity in outcomes is consistent with what similar literature reviews have found. ${ }^{[9,10]}$ Table 2 provides a list of studies of effective interventions and the characteristics of those interventions. Table 3 describes studies of ineffective interventions.

Table 2. Interventions associated with statistically significant reduction in medication-related hospital readmissions

\begin{tabular}{|c|c|c|c|c|}
\hline Author (Year) & List of intervention components & $\begin{array}{l}\text { Number of } \\
\text { intervention } \\
\text { components }\end{array}$ & $\begin{array}{l}\text { Intervention } \\
\text { group size }\end{array}$ & Study site \\
\hline $\begin{array}{l}\text { Crotty et al. } \\
\text { (2004) }\end{array}$ & $\begin{array}{l}\text { - } \quad \text { Use of pharmacist as professional coordinator } \\
\text { - } \quad \text { Pharmacist-led medication reconciliation }\end{array}$ & 2 & 56 & $\begin{array}{l}3 \text { public hospitals in } \\
\text { Australia }\end{array}$ \\
\hline $\begin{array}{l}\text { Tuso et al. } \\
\text { (2014) }\end{array}$ & $\begin{array}{l}\text { - } \quad \text { Post-discharge phone call } \\
\text { - } \quad \text { Patient education and counseling }\end{array}$ & 2 & 693 & $\begin{array}{l}13 \text { Kaiser } \\
\text { Permanente } \\
\text { hospitals, USA }\end{array}$ \\
\hline Warden (2014) & $\begin{array}{ll}\text { - } & \text { Discharge planning } \\
\text { - } & \text { Discharge education } \\
\text { - } & \text { Post-discharge phone call } \\
\text { - } & \text { Use of pharmacist as professional coordinator } \\
\text { - } & \text { Patient education and counseling } \\
\text { - } & \text { Pharmacist-led medication reconciliation }\end{array}$ & 6 & 35 & $\begin{array}{l}\text { Academic medical } \\
\text { center, USA }\end{array}$ \\
\hline $\begin{array}{l}\text { Arnold et al. } \\
\text { (2015) }\end{array}$ & $\begin{array}{l}\text { - Use of pharmacist as professional coordinator } \\
\text { - } \quad \text { Pharmacist-led medication reconciliation }\end{array}$ & 2 & 98 & $\begin{array}{l}\text { Outpatient teaching } \\
\text { clinic }\end{array}$ \\
\hline $\begin{array}{l}\text { Balling et al. } \\
\text { (2015) }\end{array}$ & $\begin{array}{ll}\text { - } & \text { Discharge planning } \\
\text { - } & \text { Discharge education } \\
\text { - } & \text { Use of pharmacist as professional coordinator } \\
\text { - } & \text { Patient education and counseling } \\
\text { - } & \text { Pharmacist-led medication reconciliation }\end{array}$ & 5 & 1,058 & $\begin{array}{l}\text { Academic medical } \\
\text { center, USA }\end{array}$ \\
\hline $\begin{array}{l}\text { Blee et al. } \\
(2015)\end{array}$ & - Discharge education & 1 & 208 & $\begin{array}{l}2 \text { academic medical } \\
\text { centers, USA }\end{array}$ \\
\hline $\begin{array}{l}\text { Blagburn et al. } \\
\text { (2016) }\end{array}$ & $\begin{array}{l}\text { - } \quad \text { Discharge planning } \\
\text { - } \quad \text { Discharge education } \\
\text { - } \quad \text { Use of pharmacist as professional coordinator } \\
\text { - } \quad \text { Pharmacist-led medication reconciliation }\end{array}$ & 4 & 418 & $\begin{array}{l}\text { Academic medical } \\
\text { center, UK }\end{array}$ \\
\hline $\begin{array}{l}\text { Phatak et al. } \\
\text { (2016) }\end{array}$ & $\begin{array}{ll}\text { - } & \text { Discharge planning } \\
\text { - } & \text { Discharge education } \\
\text { - } & \text { Post-discharge phone call } \\
\text { - } & \text { Patient education and counseling } \\
\text { - } & \text { Pharmacist-led medication reconciliation }\end{array}$ & 5 & 137 & $\begin{array}{l}\text { Academic medical } \\
\text { center, USA }\end{array}$ \\
\hline
\end{tabular}

Unfortunately, there are few obvious differences between the interventions associated with significant reductions in readmissions and those that were not. Interventions in both groups frequently employed a professional coordinator and involved medication reconciliation efforts. Both groups included interventions with only one or two components as well as more comprehensive interventions. 
Table 3. Interventions not associated with statistically significant reduction in medication-related hospital readmissions

\begin{tabular}{|c|c|c|c|c|}
\hline Author (Year) & List of intervention components & $\begin{array}{l}\text { Number of } \\
\text { intervention } \\
\text { components }\end{array}$ & $\begin{array}{l}\text { Intervention } \\
\text { group size }\end{array}$ & Study site \\
\hline $\begin{array}{l}\text { Hyrkas et al. } \\
\text { (2012) }\end{array}$ & $\begin{array}{ll}\text { - } & \text { Discharge education } \\
\text { - } & \text { Provider education }\end{array}$ & 2 & 205 & $\begin{array}{l}600 \text { bed hospital, } \\
\text { USA }\end{array}$ \\
\hline $\begin{array}{l}\text { Bonnet-Zamponi } \\
\text { et al. (2013) }\end{array}$ & $\begin{array}{ll}\text { - } & \text { Discharge planning } \\
\text { - } & \text { Discharge education } \\
\text { - } & \text { Use of physician as a professional coordinator } \\
\text { - } & \text { Patient education and counseling } \\
\text { - } & \text { Physician-led medication reconciliation }\end{array}$ & 5 & 317 & $\begin{array}{l}6 \text { acute care } \\
\text { hospitals, USA }\end{array}$ \\
\hline $\begin{array}{l}\text { Marusic et al. } \\
\text { (2013) }\end{array}$ & - Discharge education & 1 & 80 & $\begin{array}{l}\text { Academic medical } \\
\text { center, Croatia }\end{array}$ \\
\hline $\begin{array}{l}\text { Eisenhower } \\
\text { (2014) }\end{array}$ & $\begin{array}{l}\text { - Use of pharmacist as a professional coordinator } \\
\text { - } \quad \text { Pharmacist-led medication reconciliation }\end{array}$ & 2 & 25 & $\begin{array}{l}800 \text { bed community } \\
\text { teaching hospital, } \\
\text { USA }\end{array}$ \\
\hline $\begin{array}{l}\text { Linden et al. } \\
\text { (2014) }\end{array}$ & $\begin{array}{ll}\text { - } & \text { Discharge education } \\
\text { - } & \text { Post-discharge phone call } \\
\text { - } & \text { Use of nurse as a professional coordinator } \\
\text { - } & \text { Patient education and counseling }\end{array}$ & 4 & 253 & $\begin{array}{l}2 \text { community } \\
\text { hospitals, USA }\end{array}$ \\
\hline $\begin{array}{l}\text { Soong et al. } \\
\text { (2014) }\end{array}$ & $\begin{array}{ll}\text { - } & \text { Post-discharge phone call } \\
\text { - } & \text { Patient education and counseling }\end{array}$ & 2 & 114 & $\begin{array}{l}\text { Academic medical } \\
\text { center, Canada }\end{array}$ \\
\hline $\begin{array}{l}\text { Vinluan et al. } \\
\text { (2014) }\end{array}$ & $\begin{array}{ll}\text { - } & \text { Discharge education } \\
\text { - } & \text { Post-discharge phone call } \\
\text { - } & \text { Patient education and counseling } \\
\text { - } & \text { Pharmacist-led medication reconciliation }\end{array}$ & 4 & 7 & $\begin{array}{l}\text { Community teaching } \\
\text { hospital, USA }\end{array}$ \\
\hline $\begin{array}{l}\text { Gilmore et al. } \\
\text { (2015) }\end{array}$ & $\begin{array}{ll}\text { - } & \text { Discharge planning } \\
\text { - } & \text { Discharge education } \\
\text { - } & \text { Post-discharge phone call } \\
\text { - } & \text { Patient education and counseling } \\
\text { - } & \text { Provider education } \\
\text { - } & \text { Pharmacist-led medication reconciliation for complex cases }\end{array}$ & 6 & Not reported & $\begin{array}{l}\text { Academic medical } \\
\text { center, USA }\end{array}$ \\
\hline $\begin{array}{l}\text { Kalista et al. } \\
\text { (2015) }\end{array}$ & $\begin{array}{l}\text { - } \quad \text { Post-discharge phone call } \\
\text { - } \quad \text { Use of community pharmacist as a professional coordinator } \\
\text { - } \quad \text { Patient education and counseling } \\
\text { - }\end{array}$ & 4 & 10 & $\begin{array}{l}\text { Home health agency, } \\
\text { community } \\
\text { pharmacy, USA }\end{array}$ \\
\hline $\begin{array}{l}\text { Budiman et al. } \\
\text { (2016) }\end{array}$ & $\begin{array}{ll}\text { - } & \text { Discharge planning } \\
\text { - } & \text { Discharge education } \\
\text { - } & \text { Use of physician as a professional coordinator } \\
\text { - } & \text { Patient education and counseling } \\
\text { - } & \text { Pharmacist-led medication reconciliation }\end{array}$ & 5 & 40 & $\begin{array}{l}\text { Academic medical } \\
\text { center, USA }\end{array}$ \\
\hline Frail et al. (2016) & $\begin{array}{l}\text { - } \quad \text { Post-discharge phone call } \\
\text { - } \quad \text { Use of community pharmacist as a professional coordinator } \\
\text { - } \quad \text { Patient education and counseling } \\
\text { - } \quad \text { Pharmacist-led medication reconciliation }\end{array}$ & 4 & 18 & $\begin{array}{l}92 \text { bed rural } \\
\text { community hospital, } \\
\text { retail community } \\
\text { pharmacy, USA }\end{array}$ \\
\hline $\begin{array}{l}\text { Miller et al. } \\
\text { (2016) }\end{array}$ & $\begin{array}{ll}\text { - } & \text { Post-discharge phone call } \\
\text { - } & \text { Use of pharmacist as professional coordinator } \\
\text { - } & \text { Patient education and counseling }\end{array}$ & 3 & 314 & $\begin{array}{l}\text { US hospital } \\
\text { (additional detail not } \\
\text { provided) }\end{array}$ \\
\hline $\begin{array}{l}\text { Patton et al. } \\
\text { (2017) }\end{array}$ & $\begin{array}{l}\text { - } \quad \text { Post-discharge phone call } \\
\text { - } \quad \text { Use of community pharmacist as a professional coordinator } \\
\text { - } \quad \text { Patient education and counseling } \\
\text { - } \quad \text { Pharmacist-led medication reconciliation }\end{array}$ & 4 & 9 & $\begin{array}{l}60 \text { bed rural hospital } \\
\text { and community } \\
\text { pharmacy, USA }\end{array}$ \\
\hline
\end{tabular}




\subsection{Site of care}

Most of the interventions studied were implemented within the inpatient setting. Interventions implemented in academic medical centers (AMCs) seem slightly more likely to be successful. Five (5) of the 8 effective interventions were implemented in AMCs while only 5 of the 13 ineffective interventions were implemented in AMCs. In addition to the interventions we identified that were implemented by inpatient facilities, we also identified 4 interventions established by other types of providers. One (1) of these interventions ${ }^{[33]}$ was successful. This intervention was based in a large outpatient teaching clinic. Of the other 3 interventions initiated by non-hospital providers, 2 were community hospital-community pharmacy partnerships, ${ }^{[29,30]}$ while 1 was a partnership between a home health agency and a community pharmacy. ${ }^{[28]}$ These 3 interventions were not associated with a statistically significant reduction in readmissions. However, this could have been because these studies each had small sample sizes (ranging from 9-18 patients).

\subsection{Subgroup analysis of large studies}

Because many of the studies included in our research had small sample sizes and likely lacked the power to detect a statistically significant effect, we also performed a subgroup analysis in which we only included studies with an intervention group size of 85 or more patients. This reduced the number of studies in this subgroup to 11 . Of these 11 studies, 6 found statistically significant declines in readmissions for the interventions studied while 5 did not. The inclusion of medication reconciliation as an intervention component was one of the clearest factors distinguishing successful from unsuccessful interventions. Four of the 6 successful interventions included a medication reconciliation component whereas only 1 of the unsuccessful interventions included medication reconciliation. In all successful interventions, medication reconciliation was led by a pharmacist. Similarly, discharge planning was present in a higher percentage of successful interventions than unsuccessful ones. Three of the 6 successful interventions included discharge planning compared to one of the 5 unsuccessful ones.

Other intervention components (discharge education, inclusion of post discharge phone calls, the use of a professional coordinator and patient education efforts) were relatively prevalent in both successful and unsuccessful interventions. For instance, 4 of the 6 successful studies included a discharge education component, but 3 of the 5 unsuccessful studies did as well. Similarly, 2 of 6 successful studies included a post-discharge phone call but 3 of the 5 unsuccessful studies also included post-discharge phone call. Half of the successful and 3 of the 5 unsuccessful studies included a professional coordinator.

\section{DiscuSsion}

One of the most striking results of our study is the similarity between the strategies used in the successful interventions and the strategies used in the unsuccessful ones. This suggests that contextual and organizational factors may be more important in an intervention's success than the intervention's structural elements. For instance, it may be the case that the content of a post-discharge telephone call and the personality of the individual making the call are more important to a program's success than whether or not it includes a postdischarge telephone call. Unfortunately, many of the articles included in our study offered limited detail on the contextual aspects of their interventions. One result of our review is that future research in readmission reduction could benefit from qualitative designs or expertise from implementation science to identify the critical characteristics of an intervention that result in success or failure. At present, the literature evaluating medication-related readmission reduction programs may be a useful guide for clinicians working to establish new programs, but it should be complemented by interviews with professionals who have experience managing successful programs at similar institutions. One reason for the wide variety of successful structures may be that, even though the target of these interventions was narrowly-defined (medication-related readmissions), studies differed in a number of characteristics. These included the target population, which ranged from a broadly defined population (for instance, all patients discharged from a specific medical-surgical unit) to very narrowly defined populations (for instance, patients who received a cardiac stent). It is possible that some strategies are more or less effective for different patient populations. Future work should consider clinical differences in patient populations, particularly clinical complexity and the presence of multiple comorbidities, and how these differences may affect the efficacy of studied interventions. In addition, it is likely that factors like a patient's social support systems play an important but understudied role in intervention effectiveness.

Studies also differed in terms of the exact readmission measure, both the time associated with readmission (ranging from 30 to 180 days from discharge) and the reason for readmission (e.g., all cause readmissions vs. readmissions for a specific condition) and these different outcomes could have contributed to the inconsistency with which certain interventions were found to be effective. Studies also varied in the health system in which the intervention was taking place (US hospital vs. international hospital, AMC vs. community hospital). The variety of health system contexts in which studies 
took place is particularly challenging since most studies estimated the effects of the intervention using either a concurrent or historical control. Usual care and customary discharge processes varied by context, though many articles provided little information on these factors. The effect of a particular intervention component likely depends on the usual care to which it is compared. For instance, the effect of an additional post-discharge phone call, may be minimal when compared to a typical discharge process that includes pre-discharge counseling with a pharmacist but substantial when compared with a discharge process that includes less comprehensive medication counselling. One theme that did emerge from our review is that interventions undertaken by AMCs seem more likely to be successful than those undertaken by smaller hospitals or those interventions housed outside of acute-care facilities. This is somewhat surprising given the communication challenges posed by AMCs' size and organizational complexity, as well as the clinical complexity of the patients treated in AMCs. The success of interventions undertaken by AMCs may be a result of these facilities having more pharmacy resources than community hospitals or because AMCs tend to adopt more advanced pharmacy practice models. ${ }^{[34]}$ Future research may examine differences between interventions implemented in AMCs and those instituted in other settings to identify ways that successful AMC-based interventions could be adapted to other facilities.

\section{Issues in assessing intervention success}

Our study classified interventions as successful or unsuccessful based on whether the studied intervention was associated with a statistically significant reductions in readmission rates. While this is a rigorous criterion, its use as a measure of intervention success is problematic for several reasons. Many of the studies examining interventions that did not reduce readmissions cited other benefits of the interventions, particularly in measures of potential readmission causes. For example, one study describes an intervention to improve patient counselling that resulted in improved medication adherence, but did not produce a statistically significant reduction in readmissions. ${ }^{[20]}$ Similarly, another study describes an intervention that successfully improved medication adherence and literacy but produced a reduction in readmissions that failed to meet the criteria of statistical significance. ${ }^{[32]}$ In addition, many of the interventions were tested on a small sample of patients making statistical significance more difficult to attain. Several of these studies were likely published with the intent of being proof of concept case studies or to demonstrate a new care model was feasible rather than to truly evaluate its effectiveness. ${ }^{[26,27]}$ When we limited our sample to studies with larger samples, we found more definitive results. In particular, medication reconciliation and discharge planning were present in far more of the successful interventions than the unsuccessful ones, suggesting that these may be critical components to include in interventions designed to reduce medication readmissions. This finding also highlights one of the challenges for researchers hoping to produce findings that inform practice. On one hand, it appears that relatively large studies are required to rigorously evaluate an intervention's success in reducing readmissions. On the other, larger studies may make it more challenging for researchers to collect information about the contextual elements of an intervention (for example, an individual pharmacist's process for medication reconciliation) and we believe these contextual elements are critical in determining the success of a particular intervention component.

\section{Conclusions}

Readmission reduction continues to be a pressing problem for health systems seeking to avoid Medicare penalties and improve the quality of care they offer patients. The body of literature on efforts to reduce medication-related hospital readmissions is growing and providers implementing interventions to address medication-related readmission factors seem to be using a relatively consistent set of intervention components. When we considered all the relevant literature, none of these components have emerged as being consistently associated with measurable reductions in readmissions. However, our analysis of a subsample of larger studies suggested that pharmacist-led medication reconciliation and discharge planning may be critical components of programs addressing medication-related causes of readmissions. In the future, researchers and program managers should work to identify the contextual factors critical to intervention success and to understand how successful interventions established in academic medical centers can be adapted to other sites of care. The findings of this review will benefit clinicians and managers designing programs to reduce medication-related readmissions, policymakers seeking to understand how providers are responding to the incentives posed by the HRRP, and researchers examining readmission reduction efforts.

\section{ACKNOWLEDGEMENTS}

This work was funded by the National Science Foundation's Center for Healthcare Organization and Transformation (CHOT) grant NSF1624690.

\section{CONFlicts OF INTEREST Disclosure}

The authors declare they have no conflicts of interest. 


\section{REFERENCES}

[1] Kathryn Fingar and Raynard Washington. Agency for Healthcare Research and Quality. Statistical Brief \#196: Trends in Hospital Readmissions for Four High-Volume Conditions, 2009-2013. Published November 2015. Accessed February 1, 2018. Available from: https: //www.hcup-us.ahrq.gov/reports/statbriefs/sb196-R eadmissions-Trends-High-Volume-Conditions.jsp.

[2] Hines A, Barrett M, Jiang HJ, et al. Agency for Healthcare Research and Quality. Statistical Brief \#172: Conditions With the Largest Number of Adult Hospital Readmissions by Payer, 2011. Published April 2014. Accessed February 1, 2018. Available from: https://www.hcup-us.ahrq.gov/reports/statbrief s/sb172-Conditions-Readmissions-Payer.jsp.

[3] American Hospital Association. Hospital Readmission Reduction Program Fact Sheet. Published August, 2016. Accessed April 1, 2018. Available from: https://www. aha.org/system/files/2 018-01/fs-readmissions.pdf.

[4] Hansen LO, Young RS, Hinami K, et al. Interventions to reduce 30-day rehospitalization: A systematic review. Annals of Internal Medicine. 2011; 155(8): 520-528. PMid:22007045. https: //doi.org/10.7326/0003-4819-155-8-201110180-00008

[5] Dalleur O, Beeler PE, Schnipper JL, et al. 30-Day Potentially Avoidable Readmissions Due to Adverse Drug Events. Journal of Patient Safety. 2017. PMid:28306610. https://doi .org/10.1097/PTS. 0000000000000346

[6] Polinski JM, Moore JM, Kyrychenko P, et al. An insurer's care transition program emphasizes medication reconciliation, reduces readmissions and costs. Health Affairs. 2016; 35(7): 1222-1229. PMid:27385237. https://doi .org/10.1377/hlthaff . 2015.0 648

[7] Bradley EH, Curry L, Horwitz LI, et al. Hospital Strategies Associated with 30-Day Readmission Rates for Patients with Heart Failure. Circulation. Cardiovascular Quality and Outcomes. 2013; 6(4): 444450. PMid:23861483. https://doi org/10.1161/CIRCOUTCOM ES. 111.000101

[8] Kripalani S, Theobald CN, Anctil B, et al. Reducing Hospital Readmission: Current Strategies and Future Directions. Annual Review of Medicine. 2014; 65: 471-485. PMid:24160939. https: //doi.org/10.1146/annurev-med-022613-090415

[9] Renaudin P, Boyer L, Esteve MA, et al. Do pharmacist-led medication reviews in hospitals help reduce hospital readmissions? A systematic review and meta-analysis. British Journal of Clinical Pharmacology. 2016; 82(6): 1660-1673. PMid:27511835. https : //doi.org/10.1111/bcp.13085

[10] Kvedar JC, Mekonnen AB, McLachlan AJ, et al. Effectiveness of pharmacist-led medication reconciliation programmes on clinical outcomes at hospital transitions: a systematic review and meta-analysis. Journal of Medical Internet Research. 2016; 6(2): e010003. PMid:26908524. https://doi.org/10.1136/bmjope n-2015-010003

[11] Young L, Barnason S, Hays K, et al. Nurse Practitioner-led Medication Reconciliation in Critical Access Hospitals. Journal for Nurse Practitioners. 2015; 11(5): 511-518. https://doi.org/10.1016/ j.nurpra.2015.03.005

[12] Setter SM, Corbett CF, Neumiller JJ, et al. Effectiveness of a pharmacist-nurse intervention on resolving medication discrepancies for patients transitioning from hospital to home health care. American Journal of Health-System Pharmacy. 2009; 66(22): 2027-2031. PMid:19890086. https://doi.org/10.2146/ajhp080582

[13] Cawthon C, Walia S, Osborn CY, et al. Improving care transitions: The patient perspective. Journal of Health Communication. 2012;
17(SUPPL. 3): 312-324. PMid:23030579. https://doi.org/10 $.1080 / 10810730.2012 .712619$

[14] Hume AL, Kirwin J, Bieber HL, et al. Improving care transitions: Current practice and future opportunities for pharmacists. Pharmacotherapy. 2012; 32(11): e326-e337. PMid:23108810. https : //doi.org/10.1002/phar.1215

[15] Knisely MR, Bartlett Ellis RJ, Carpenter JS. Complexities of medication management across care transitions: A case report. Clinical Nurse Specialist. 2015; 29(5): E1-E7. PMid:26258840. https : //doi.org/10.1097/NUR.0000000000000141

[16] Retrum JH, Boggs J, Hersh A, et al. Patient-identified factors related to heart failure readmissions. Circulation: Cardiovascular Quality and Outcomes. 2013; 6(2): 171-177. PMid:23386663. https: //doi.org/10.1161/CIRCOUTCOMES.112.967356

[17] Turrise S. Illness Representations, Treatment Beliefs, Medication Adherence, and 30-Day Hospital Readmission in Adults With Chronic Heart Failure: A Prospective Correlational Study. The Journal of Cardiovascular Nursing. 2016; 31(3): 245-254. PMid:25774845. https://doi.org/10.1097/JCN.0000000000000249

[18] Laugaland K, Aase K, Barach P. Interventions to improve patient safety in transitional care-a review of the evidence. Work. 2012; 41(Suppl 1): 2915-2924.

[19] Blee J, Roux RK, Gautreaux S, et al. Dispensing inhalers to patients with chronic obstructive pulmonary disease on hospital discharge: Effects on prescription filling and readmission. American Journal of Health-System Pharmacy. 2015; 72(14): 1204-1208. PMid:26150570. https://doi.org/10.2146/ajhp140621

[20] Marusic S, Gojo-Tomic N, Erdeljic V, et al. The effect of pharmacotherapeutic counseling on readmissions and emergency department visits. International Journal of Clinical Pharmacy. 2013; 35(1): 37-44. PMid:23007693. https://doi .org/10.1007/s11096-0 12-9700-9

[21] Warden BA, Freels JP, Furuno JP, et al. Pharmacy-managed program for providing education and discharge instructions for patients with heart failure. American Journal of Health-System Pharmacy. 2014; 71(2): 134-139. PMid:24375606. https://doi .org/10.2146/aj hp130103

[22] Balling L, Erstad BL, Weibel K. Impact of a transition-of-care pharmacist during hospital discharge. Journal of the American Pharmacists Association: JAPhA. 2015; 55(4): 443-448. PMid:26161488. https://doi.org/10.1331/JAPhA.2015.14087

[23] Blagburn J, Kelly-Fatemi B, Akhter N, et al. Person-centred pharmaceutical care reduces emergency readmissions. European Journal of Hospital Pharmacy. 2016; 23(2): 80-85. PMid:27019710. https://doi.org/10.1136/ejhpharm-2015-000736

[24] Phatak A, Prusi R, Ward B, et al. Impact of pharmacist involvement in the transitional care of high-risk patients through medication reconciliation, medication education, and postdischarge call-backs (IPITCH Study). Journal of Hospital Medicine. 2016; 11(1): 39-44. PMid:26434752. https://doi.org/10.1002/jhm.2493

[25] Linden A, Butterworth S. A comprehensive hospital-based intervention to reduce readmissions for chronically ill patients: a randomized controlled trial. American Journal of Managed Care. 2014; 20(10): 783-792.

[26] Vinluan CM, Wittman D, Morisky D. Effect of pharmacist discharge counselling on medication adherence in elderly heart failure patients: A pilot study. Journal of Pharmaceutical Health Services Research 2015; 6(2): 103-110. https://doi.org/10.1111/jphs. 12093

[27] Gilmore V, Efird L, Fu D, et al. Implementation of transitions-of-care services through acute care and outpatient pharmacy collaboration. American Journal of Health-System Pharmacy. 2015; 72(9): 737-744. PMid:25873621. https://doi.org/10.2146/ajhp140504 
[28] Kalista T, Lemay V, Cohen L. Postdischarge community pharmacistprovided home services for patients after hospitalization for heart failure. Journal of the American Pharmacists Association: JAPhA. 2015; 55(4): 438-442. PMid:26161487. https://doi.org/10.1 331/JAPhA . 2015.14235

[29] Frail CK, Garza OW, Haas AL. Experience with technologysupported transitions of care to improve medication use. Journal of the American Pharmacists Association. 2016; 56(5): 568-572. PMid:27521168. https ://doi.org/10.1016/j.japh.2016.04 .565

[30] Patton AP, Liu Y, Hartwig DM, et al. Community pharmacy transition of care services and rural hospital readmissions: A case study. Journal of the American Pharmacists Association. 2017; 57(3): S252S258.e253. PMid:28412054. https://doi.org/10.1016/j.ja ph. 2017.02 .019

[31] Bonnet-Zamponi D, d'Arailh L, Konrat C, et al. Drug-related readmissions to medical units of older adults discharged from acute geriatric units: results of the Optimization of Medication in AGEd multicenter randomized controlled trial. Journal of the American
Geriatrics Society. 2013; 61(1): 113-121. PMid:23252914. https : //doi.org/10.1111/jgs.12037

[32] Budiman T, Snodgrass K, Komatsu Chang A. Evaluation of Pharmacist Medication Education and Post-discharge Follow-up in Reducing Readmissions in Patients With ST-Segment Elevation Myocardial Infarction (STEMI). The Annals of Pharmacotherapy. 2016; 50(2): 118-124. PMid:26681443. https://doi.org/10.1177/106002 8015620425

[33] Arnold ME, Buys L, Fullas F. Impact of pharmacist intervention in conjunction with outpatient physician follow-up visits after hospital discharge on readmission rate. American Journal of Healthsystem Pharmacy. 2015; 72(11): S36-S42. PMid:25991594. https : //doi.org/10.2146/sp150011

[34] Pedersen CA, Schneider PJ, Scheckelhoff DJ. ASHP national survey of pharmacy practice in hospital settings: Monitoring and patient education-2009. American Journal of Health-System Pharmacy. 2010; 67(7): 542-558. PMid:20237382. https://doi .org/10.2 146/ajhp090596 